Article

\title{
Combustion Characteristics of Single Particles from Bituminous Coal and Pine Sawdust in $\mathrm{O}_{2} / \mathrm{N}_{2}, \mathrm{O}_{2} / \mathrm{CO}_{2}$, and $\mathrm{O}_{2} / \mathrm{H}_{2} \mathrm{O}$ Atmospheres
}

\author{
Kai Lei ${ }^{1,2}$, Buqing Ye ${ }^{1,2}$, Jin Cao ${ }^{1,2}$, Rui Zhang ${ }^{1,2, *}$ and Dong Liu 1,2,* \\ 1 Ministry of Industry and Information Technology Key Laboratory of Thermal Control of Electronic \\ Equipment, School of Energy and Power Engineering, Nanjing University of Science \& Technology, \\ Nanjing 210094, China; kailei@njust.edu.cn (K.L.); yebuqing@njust.edu.cn (B.Y.); jincao@njust.edu.cn (J.C.) \\ 2 Advanced Combustion Laboratory, School of Energy and Power Engineering, \\ Nanjing University of Science \& Technology, Nanjing 210094, China \\ * Correspondence: zhangrui@njust.edu.cn (R.Z.); dongliu@njust.edu.cn (D.L.)
}

Received: 25 September 2017; Accepted: 18 October 2017; Published: 25 October 2017

\begin{abstract}
Burning fuels in an $\mathrm{O}_{2} / \mathrm{H}_{2} \mathrm{O}$ atmosphere is regarded as the next generation of oxy-fuel combustion for $\mathrm{CO}_{2}$ capture and storage (CCS). By combining oxy-fuel combustion and biomass utilization technology, $\mathrm{CO}_{2}$ emissions could be further reduced. Therefore, this work focuses on investigating the combustion characteristics of single particles from bituminous coal (BC) and pine sawdust (PS) in $\mathrm{O}_{2} / \mathrm{N}_{2}, \mathrm{O}_{2} / \mathrm{CO}_{2}$ and $\mathrm{O}_{2} / \mathrm{H}_{2} \mathrm{O}$ atmospheres at different $\mathrm{O}_{2}$ mole fractions $(21 \%, 30 \%$, and $40 \%)$. The experiments were carried out in a drop tube furnace (DTF), and a high-speed camera was used to record the combustion processes of fuel particles. The combustion temperatures were measured by a two-color method. The results reveal that the particles from BC and PS all ignite homogeneously. Replacing $\mathrm{N}_{2}$ by $\mathrm{CO}_{2}$ results in a longer ignition delay time and lower combustion temperatures. After substituting $\mathrm{H}_{2} \mathrm{O}$ for $\mathrm{N}_{2}$, the ignition delay time is shortened, which is mainly caused by the steam gasification reaction $\left(\mathrm{C}+\mathrm{H}_{2} \mathrm{O} \rightarrow \mathrm{CO}+\mathrm{H}_{2}\right)$ and steam shift reaction $\left(\mathrm{CO}+\mathrm{H}_{2} \mathrm{O} \rightarrow \mathrm{CO}_{2}+\mathrm{H}_{2}\right)$. In addition, the combustion temperatures are first decreased at low $\mathrm{O}_{2}$ mole fractions, and then increased at high $\mathrm{O}_{2}$ mole fractions because the oxidation effect of $\mathrm{H}_{2} \mathrm{O}$ performs a more important role than its volumetric heat capacity and thermal radiation capacity. At the same condition, particles from PS ignite earlier because of their higher reactivity, but the combustion temperatures are lower than those of $\mathrm{BC}$, which is owing to their lower calorific values.
\end{abstract}

Keywords: oxy-fuel combustion; $\mathrm{O}_{2} / \mathrm{H}_{2} \mathrm{O}$; single particle; bituminous coal (BC); pine sawdust (PS)

\section{Introduction}

Coal will continue to be one of the major energy resources over the next few decades due to its low price and rich reserves. It is reported that coal's share of the global primary energy consumption is $28.1 \%$ in 2016 [1]. However, the emission of $\mathrm{CO}_{2}$ generated by coal-fired power plants is one of the most important factors leading to global warming [2-4]. In order to reduce the emission of $\mathrm{CO}_{2}$, strategies need to be devised.

Oxy-fuel combustion is regarded as a promising technology for facilitating $\mathrm{CO}_{2}$ capture and storage (CCS) by using the mixture of $\mathrm{O}_{2}$ and recycled flue gas as an oxidizer, instead of air. Thus, a high concentration of $\mathrm{CO}_{2}$ can be obtained in the flue gas, and only a small amount of follow-up work is required to achieve the capture and storage of $\mathrm{CO}_{2}$. Therefore, oxy-fuel combustion has attracted considerable attention in recent years [5-9].

In 2010, Seepana and Jayanti [10] proposed a new variant of oxy-fuel combustion, called steam-moderated oxy-fuel combustion (SMOC). It burns fuel in a mixture of $\mathrm{O}_{2}$ and steam, 
the exhausted gas mainly contains steam and $\mathrm{CO}_{2}$, which can be sent for compression and sequestration after the condensation of steam. Compared with the $\mathrm{O}_{2} / \mathrm{CO}_{2}$ recycled combustion, the most significant advantage of SMOC is that the flue gas recirculation system is avoided, therefore, the layout of the plant is simplified and the overall system is easy to start and shut down. Furthermore, the pumping costs are lower because the transmission medium is water, instead of hot flue gas [11]. Finally, the formation of $\mathrm{NO}_{X}$ and $\mathrm{SO}_{X}$ is limited because of the presence of steam [10]. Owing to the advantages of SMOC, researchers have started to study the combustion behaviors of pulverized coal in an $\mathrm{O}_{2} / \mathrm{H}_{2} \mathrm{O}$ environment [11-17].

Another method to reduce $\mathrm{CO}_{2}$ emission is the utilization of biomass [18-20]. Firing biomass for electricity generation can not only ease the energy crisis, but also reduce the emission of $\mathrm{CO}_{2}$ because the carbon contained in biomass comes from $\mathrm{CO}_{2}$ in the atmosphere. In addition, the emission of $\mathrm{NO}_{X}$ and $\mathrm{SO}_{X}$ can also be limited. Using biomass in existing coal-fired power plants only requires minor modifications, making the co-firing of biomass with coal an easier and less costly method for generating power [21]. However, the power output of a power-plant is reduced because of the lower calorific value of biomass, and the preparation of biomass fuels is influenced by many factors, such as the seasons. Furthermore, biomass contains high levels of $\mathrm{K}, \mathrm{Na}$, and $\mathrm{Cl}$, therefore, the use of biomass may result in ash-related operational problems [22]. Although using biomass for electricity generation has some limitations, it is still a competitive technology for reducing the emission of $\mathrm{CO}_{2}[23,24]$. By combining oxy-fuel combustion and biomass utilization technology, the $\mathrm{CO}_{2}$ emission could be minimized. Therefore, oxy-fuel combustion of biomass has attracted much interest $[7,21,25,26]$.

For $\mathrm{O}_{2} / \mathrm{CO}_{2}$ recycled combustion, the combustion characteristics of coal and biomass are supposed to be different from $\mathrm{O}_{2} / \mathrm{N}_{2}$ combustion, because the physical properties of $\mathrm{CO}_{2}$ are different from those of $\mathrm{N}_{2}$, especially its volumetric heat capacity and lower diffusivity of $\mathrm{O}_{2}$. Khatami et al. [6] and Molina et al. [27] reported that the ignition of pulverized coal and biomass occurred later in $\mathrm{O}_{2} / \mathrm{CO}_{2}$ atmospheres at the same $\mathrm{O}_{2}$ mole fraction, which resulted from a lower gas temperature in the furnace caused by the higher volumetric heat capacity of $\mathrm{CO}_{2}$. Khatami et al. [7], Zhang et al. [8], and Bejarano et al. [9] claimed that single coal and biomass particles burned at higher mean temperatures and shorter combustion times in $\mathrm{O}_{2} / \mathrm{N}_{2}$ than in $\mathrm{O}_{2} / \mathrm{CO}_{2}$ atmospheres. Riaza et al. [21] studied the combustion behaviors of four different pulverized biomasses in air and oxy-fuel conditions and observed that there was an obvious ignition delay of char upon extinction of the volatiles flame, and replacing the background $\mathrm{N}_{2}$ gas with $\mathrm{CO}_{2}$ reduced the combustion intensity. Compared with coal, the volatiles flame of biomass was dim due to its low calorific value.

For SMOC, the presence of steam will greatly change the physicochemical properties of the background gas, especially its reactivity [12]. Therefore, the combustion behaviors of coal and biomass are expected to be different from those in conventional or $\mathrm{O}_{2} / \mathrm{CO}_{2}$ recycled combustion. Zou and Cai et al. [11,12] numerically and experimentally studied the ignition characteristics of BC in $\mathrm{O}_{2} / \mathrm{N}_{2}$ and $\mathrm{O}_{2} / \mathrm{H}_{2} \mathrm{O}$ atmospheres and reported that the larger volumetric heat capacity and higher thermal radiation of $\mathrm{H}_{2} \mathrm{O}$ would lead to a longer ignition delay time, whereas the stronger oxidation effect of $\mathrm{H}_{2} \mathrm{O}$ would shorten the ignition delay time of BC. Cai et al. [13] then numerically investigated the ignition behaviors of $\mathrm{BC}$ in $\mathrm{O}_{2} / \mathrm{CO}_{2} / \mathrm{H}_{2} \mathrm{O}$ atmospheres and found that the lower volumetric heat capacity, higher diffusivity and stronger oxidation effect of $\mathrm{H}_{2} \mathrm{O}$, compared to $\mathrm{CO}_{2}$, would lead to earlier ignition, while the higher thermal radiation of $\mathrm{H}_{2} \mathrm{O}$ would lead to ignition delay. Prationo et al. [14] claimed that the promotional effect of $\mathrm{H}_{2} \mathrm{O}$ on ignition is more significant for low-rank coal, which is because the volatiles of low-rank coal contain more $\mathrm{CO}$ that can readily react with $\mathrm{H}_{2} \mathrm{O}$. Gil et al. [15], Yi et al. [16], and Zou et al. [17] studied the effects of $\mathrm{H}_{2} \mathrm{O}$ on the combustion behaviors of coal and biomass chars by thermogravimetric analysis and reported that the ignition of chars was delayed and the comprehensive reactivity of chars was improved with the addition of $\mathrm{H}_{2} \mathrm{O}$.

Previous studies were focused on $\mathrm{O}_{2} / \mathrm{CO}_{2}$ recycled combustion and the ignition characteristics of coal in an $\mathrm{O}_{2} / \mathrm{H}_{2} \mathrm{O}$ environment. In particular, so little has been reported on the entire combustion processes of coal or biomass under an $\mathrm{O}_{2} / \mathrm{H}_{2} \mathrm{O}$ environment, especially of biomass. However, this is 
very important for designing the oxy-steam coal-fired or biomass power plants in the future. In this paper, the combustion characteristics of single particles from BC and pine sawdust (PS) in $\mathrm{O}_{2} / \mathrm{N}_{2}$, $\mathrm{O}_{2} / \mathrm{CO}_{2}$ and $\mathrm{O}_{2} / \mathrm{H}_{2} \mathrm{O}$ atmospheres at different $\mathrm{O}_{2}$ mole fractions $(21 \%, 30 \%$ and $40 \%)$ were studied experimentally. The entire combustion processes of single particles were recorded by a high speed camera and the combustion temperatures were measured by a two-color method.

\section{Materials and Methods}

\subsection{Fuel Samples}

Hengshan BC and PS were used in this study. The raw materials were air-dried (AD) before being used. Prior to experiments, the raw materials were ground and sieved to a size of 75-100 $\mu \mathrm{m}$. The proximate, ultimate, and calorific value analysis of prepared fuel samples are given in Table 1. It is clear that the volatile content of PS is higher than that of BC, whereas the higher heating value (HHV) and fixed carbon content of PS are lower. In addition, PS has a higher content of hydrogen and oxygen, indicating that PS has a higher reactivity and is easier to achieve ignition [28,29].

Table 1. Properties of fuel samples (daf, dry-ash-free).

\begin{tabular}{|c|c|c|c|c|c|c|c|c|c|c|}
\hline \multirow{2}{*}{ Fuels } & \multicolumn{4}{|c|}{ Proximate Analysis (wt \%) } & \multicolumn{5}{|c|}{ Ultimate Analysis (wt \%) } & \multirow{2}{*}{$\begin{array}{l}\text { HHV } \\
\text { (MJ/Kg) }\end{array}$} \\
\hline & $\mathbf{M}_{\mathrm{ad}}$ & $\mathrm{V}_{\mathrm{ad}}$ & $\mathrm{FC}_{\mathrm{ad}}$ & $\mathbf{A}_{\mathrm{ad}}$ & $\mathrm{C}_{\text {daf }}$ & $\mathbf{H}_{\text {daf }}$ & $\mathrm{O}_{\text {daf }}$ & $\mathbf{N}_{\text {daf }}$ & $S_{\text {daf }}$ & \\
\hline $\mathrm{BC}$ & 7.99 & 32.68 & 50.07 & 9.26 & 67.77 & 4.14 & 25.35 & 1.01 & 1.73 & 25.74 \\
\hline PS & 4.76 & 80.61 & 14.13 & 0.50 & 48.74 & 6.88 & 44.30 & 0.08 & 0.00 & 18.73 \\
\hline
\end{tabular}

\subsection{Experimental Method}

The combustion experiments were carried out in an electrically-heated drop tube furnace (DTF) at a constant wall temperature of $1273 \mathrm{~K}$. The DTF was equipped with a transparent quartz tube with an inner diameter of $5 \mathrm{~cm}$ and $80 \mathrm{~cm}$ in length. A slidable observation window was set to the DTF. The window can be slid to a suitable position where the combustion of fuel particles could be observed. A schematic of the experimental setup is given in Figure 1. The fuel particles were introduced into the furnace from the top entrance of the furnace.

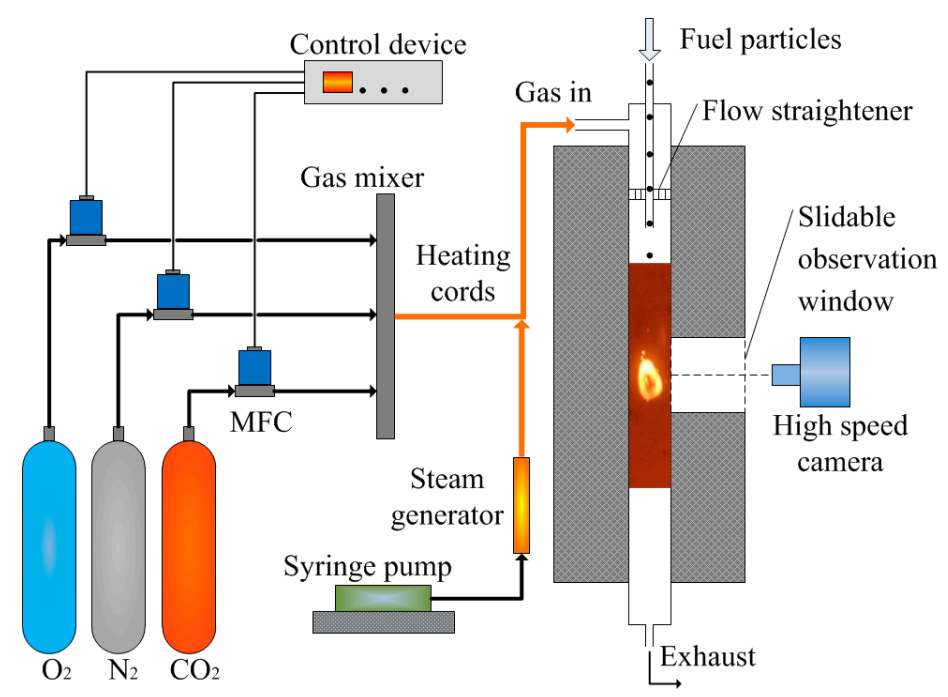

Figure 1. Schematic of the experimental setup.

The combustion behaviors of fuel particles were investigated in $\mathrm{O}_{2} / \mathrm{N}_{2}, \mathrm{O}_{2} / \mathrm{CO}_{2}$ and $\mathrm{O}_{2} / \mathrm{H}_{2} \mathrm{O}$ atmospheres under different $\mathrm{O}_{2}$ mole fractions $(21 \%, 30 \%$ and $40 \%)$. The total flow rate was set to 
$1 \mathrm{~L} / \mathrm{min}$. The flow rates of $\mathrm{N}_{2}, \mathrm{CO}_{2}$ and $\mathrm{O}_{2}$ were controlled by mass flow controllers, while the flow rate of steam was controlled via a syringe pump. The syringe pump can control the flow of distilled water, which determines the flow rate of steam exiting from the steam generator. The steam generator and heating cords were heated up to $473 \mathrm{~K}$ to achieve complete vaporization and to avoid the condensation of vapor.

A high speed camera (MIKROTRON Eosens mini1 champion, Unterschleissheim, Germany) equipped with a Nikon 24-85 mm f/2.8-4D AF Zoom-Nikkor long-distance microscope lens (Nikon, Tokyo, Japan) was used to monitor the combustion processes of fuel particles. A frame speed of $1000 \mathrm{fps}$ was chosen and the exposure time was set to $800 \mu$ s when recording the flame images.

\subsection{Measurement of Temperature}

The combustion temperatures of single particles were measured by a two-color method. Detailed theory of this method is given elsewhere [30,31]. The two-color measurement of temperature is based on Planck's law of radiation. During the combustion process of coal and biomass particles, the flame radiation wavelength ranges from $300 \mathrm{~nm}$ to $1000 \mathrm{~nm}$ and the temperature ranges from $800-2000 \mathrm{~K}$. Thus, Planck's law of radiation can be replaced by Wien's law of radiation:

$$
E_{\lambda}(T)=\varepsilon(\lambda) \frac{C_{1}}{\lambda^{5}} \exp \left(-\frac{C_{2}}{\lambda T}\right)
$$

where $E_{\lambda}\left(\mathrm{W} / \mathrm{m}^{2}\right)$ refers to the radiative energy, $\varepsilon$ is the emissivity, $\lambda(\mathrm{m})$ is the wavelength, $C_{1}$ and $C_{2}$ are the Planck constants $\left(C_{1}=3.742 \times 10^{-16} \mathrm{~W} \cdot \mathrm{m}^{2}\right.$ and $\left.C_{2}=1.4388 \times 10^{-2} \mathrm{~m} \cdot \mathrm{K}\right)$, and $T(\mathrm{~K})$ is the temperature. Therefore, the monochromatic radiative intensity can be given as:

$$
I_{\lambda}(T)=\frac{1}{\pi} \varepsilon(\lambda, T) \frac{C_{1}}{\lambda^{5}} \exp \left(-\frac{C_{2}}{\lambda T}\right)
$$

According to chromatic theory, the flame image photographed by the high speed camera is a three-color (RGB) image under their respective wavelengths $\left(\lambda_{r}=7.00 \times 10^{-7} \mathrm{~m}, \lambda_{g}=5.46 \times 10^{-7} \mathrm{~m}\right.$, $\left.\lambda_{b}=4.35 \times 10^{-7} \mathrm{~m}\right)$. The three primary colors red $(R)$, green $(G)$ and blue $(B)$ were calibrated by coefficients $K_{r}, K_{g}$ and $K_{b}$, and in combination with the Equation (2), we have:

$$
\begin{aligned}
& I_{\lambda_{r}}(T)=K_{r} R=\frac{1}{\pi} \varepsilon\left(\lambda_{r}, T\right) \frac{C_{1}}{\lambda_{r}^{5}} \exp \left(-\frac{C_{2}}{\lambda_{r} T}\right) \\
& I_{\lambda_{g}}(T)=K_{g} G=\frac{1}{\pi} \varepsilon\left(\lambda_{g}, T\right) \frac{C_{1}}{\lambda_{g}^{5}} \exp \left(-\frac{C_{2}}{\lambda_{g} T}\right) \\
& I_{\lambda_{b}}(T)=K_{b} B=\frac{1}{\pi} \varepsilon\left(\lambda_{b}, T\right) \frac{C_{1}}{\lambda_{b}^{5}} \exp \left(-\frac{C_{2}}{\lambda_{b} T}\right)
\end{aligned}
$$

where the $R, G$, and $B$ are the intensity values of red, green, and blue of each pixel, respectively. Then, the flame temperature can be deduced from the ratio of the monochromatic radiative intensity at two different and nearby wavelengths. Red $(R)$ and green $(G)$ were selected to calculate the flame temperature in this study. In consideration of the narrow variation range of wavelength and temperature, it is reasonable to assume that the emissivity is constant. From Equations (3) and (4), the temperature expression can be derived as:

$$
T=-C_{2}\left(\frac{1}{\lambda_{r}}-\frac{1}{\lambda_{g}}\right) / \ln \left(\frac{K_{r} R \lambda_{r}^{5}}{K_{g} G \lambda_{g}^{5}}\right)
$$


where $K_{r} / K_{g}$ is the only parameter that needs to be determined, and the expression of $K_{r} / K_{g}$ is given in Equation (7):

$$
\frac{K_{r}}{K_{g}}=\frac{\lambda_{g}^{5}}{\lambda_{r}^{5}} \frac{G}{R} \exp \left[-\frac{C_{2}\left(1 / \lambda_{r}-1 / \lambda_{g}\right)}{T}\right]
$$

A blackbody furnace was used to calibrate $K_{r} / K_{g}$, a frame speed of $500 \mathrm{fps}$ was selected for temperature measurement, and the exposure time was set to $30 \mu$ s to avoid the flame overexposure and the interference of the background color of the furnace. The typical radiation images captured from the blackbody furnace with temperature ranges from 1423-1873 K are shown in Figure 2. The temperature of each radiation image can be read from the blackbody furnace and the RGB values are obtained by MATLAB (MathWorks, Natick, MA, USA), thus the value of $K_{r} / K_{g}$ can be calculated. The average $K_{r} / K_{g}$ value of the ten images was used in this study. By this method, the temperature of each pixel in the flame image can be gained, and the average temperature of all pixels in a flame image is used to present the instantaneous temperature of this moment. According to the preliminary experiment, the absolute error of this method is less than $30 \mathrm{~K}$, which is accurate enough for this study.

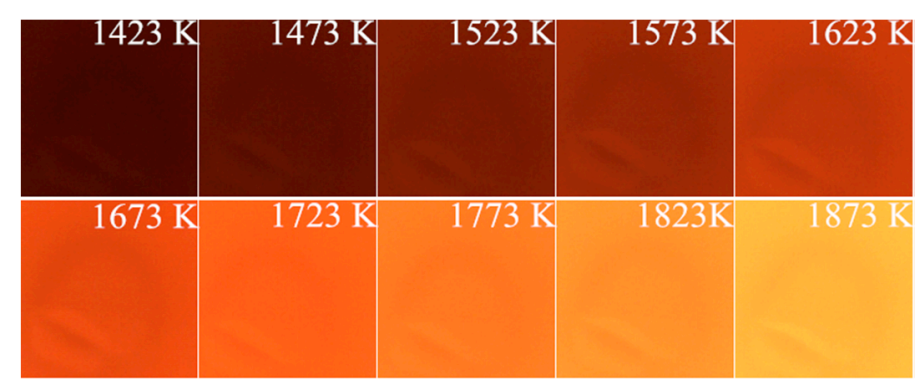

Figure 2. Typical radiation images captured from the blackbody furnace with different temperatures.

\section{Results and Discussion}

\subsection{Cinematographic Observations Analysis}

\subsubsection{Ignition Mode and Combustion Process}

The typical flame images of BC and PS particles in a simulated air condition $\left(21 \% \mathrm{O}_{2} / 79 \% \mathrm{~N}_{2}\right)$ are presented in Figure 3. It is clear that particles from BC and PS ignite homogeneously in gas mode. The devolatilization starts first when fuel particles are introduced into the furnace, then the escaped volatiles are ignited earlier than chars because of their lower ignition temperature. After ignition, a two-stage combustion process is observed. For BC, the particle is surrounded by a bright and very large diffuse flame during the volatiles combustion stage. Upon extinction of the volatiles flame, the char combustion stage starts and the flame becomes a bright spot. Unlike BC, the volatiles flame of PS is low-luminosity and almost transparent, which is due to the lower calorific value of PS. These phenomena are in agreement with the results reported by Khatami et al. [6,7] and Riaza et al. [21].

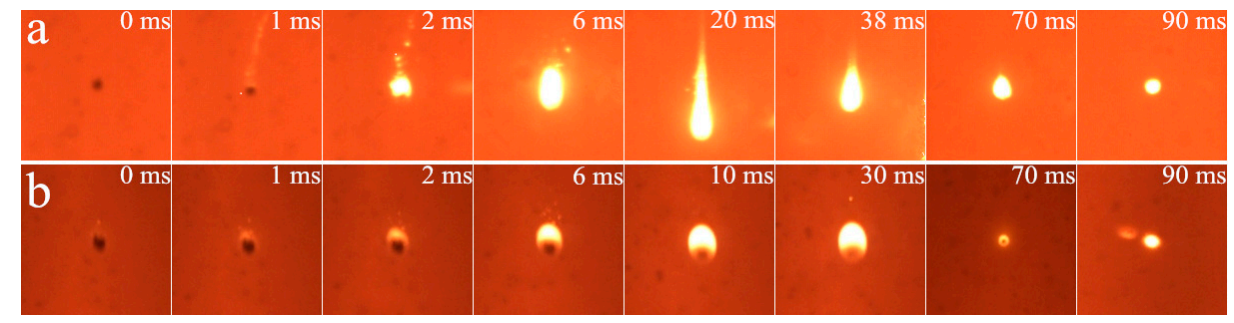

Figure 3. Typical flame images of bituminous coal (BC) and pine sawdust (PS) in $21 \% \mathrm{O}_{2} / 79 \% \mathrm{~N}_{2}$. (a) Bituminous coal (BC); and (b) pine sawdust (PS). 


\subsubsection{Effect of Diluent Gas $\left(\mathrm{N}_{2}, \mathrm{CO}_{2}\right.$ and $\left.\mathrm{H}_{2} \mathrm{O}\right)$}

The typical flame images of BC and PS in $\mathrm{O}_{2} / \mathrm{N}_{2}, \mathrm{O}_{2} / \mathrm{CO}_{2}$ and $\mathrm{O}_{2} / \mathrm{H}_{2} \mathrm{O}$ atmospheres at a $21 \%$ $\mathrm{O}_{2}$ mole fraction are shown in Figure 4. Upon replacing $\mathrm{N}_{2}$ with $\mathrm{CO}_{2}$, the combustion intensity of $\mathrm{BC}$ and PS particles is significantly reduced at the same $\mathrm{O}_{2}$ mole fraction. This is mainly contributed by the lower diffusivity of $\mathrm{O}_{2}$ in $\mathrm{CO}_{2}$ than in $\mathrm{N}_{2}$ [7]. Furthermore, the volumetric heat capacity of $\mathrm{CO}_{2}$ is $460 \mathrm{~J} / \mathrm{K} \cdot \mathrm{m}^{3}$ at $1273 \mathrm{~K}$, which is much larger than that of $\mathrm{N}_{2}\left(325 \mathrm{~J} / \mathrm{K} \cdot \mathrm{m}^{3}\right)$. Larger volumetric heat capacity of background gas causes a lower gas temperature in the furnace under active flow conditions [6]. This causes the lower devolatilization rate and lower quantity of volatiles of fuel particles, therefore, resulting in a lower combustion intensity in $\mathrm{O}_{2} / \mathrm{CO}_{2}$ atmospheres. These results are in agreement with previous studies which were carried out for coal and biomass particles [7-9,21]. After substituting $\mathrm{H}_{2} \mathrm{O}$ for $\mathrm{N}_{2}$, the similar phenomena are observed. The volumetric heat capacity of $\mathrm{H}_{2} \mathrm{O}$ is $427 \mathrm{~J} / \mathrm{K} \cdot \mathrm{m}^{3}$ at $1273 \mathrm{~K}$ and is also larger than that of $\mathrm{N}_{2}$. Thus, a high concentration of $\mathrm{H}_{2} \mathrm{O}$ in the furnace will reduce the background gas temperature. In addition, the emission capacity of $\mathrm{H}_{2} \mathrm{O}$ is higher than that of $\mathrm{N}_{2}$, and this will cause higher radiant heat transfer and decrease the temperature of fuel particles [17]. Therefore, a high concentration of $\mathrm{H}_{2} \mathrm{O}$ will decrease the combustion intensity in $\mathrm{O}_{2} / \mathrm{H}_{2} \mathrm{O}$ atmospheres.

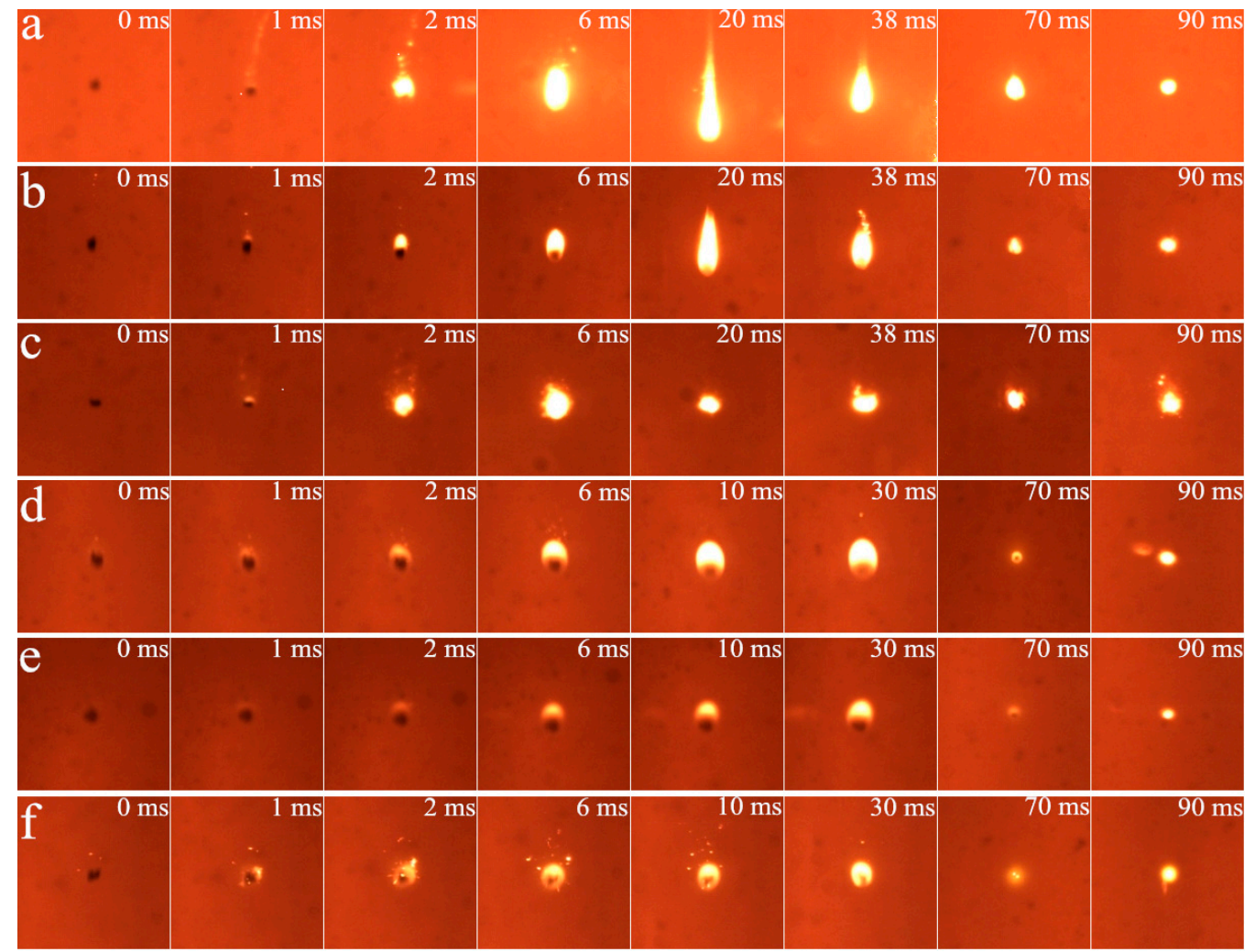

Figure 4. The influences of diluent gas on the combustion characteristics of BC and PS particles. (a) $\mathrm{BC}-21 \% \mathrm{O}_{2}+79 \% \mathrm{~N}_{2}$; (b) $\mathrm{BC}-21 \% \mathrm{O}_{2}+79 \% \mathrm{CO}_{2}$; (c) $\mathrm{BC}-21 \% \mathrm{O}_{2}+79 \% \mathrm{H}_{2} \mathrm{O}$; (d) $\mathrm{PS}-21 \% \mathrm{O}_{2}+79 \% \mathrm{~N}_{2}$; (e) $\mathrm{PS}-21 \% \mathrm{O}_{2}+79 \% \mathrm{CO}_{2}$; and (f) $\mathrm{PS}-21 \% \mathrm{O}_{2}+79 \% \mathrm{H}_{2} \mathrm{O}$.

\subsubsection{Effect of $\mathrm{O}_{2}$ Mole Fraction}

As the $\mathrm{O}_{2}$ mole fraction increases, the combustion intensity of $\mathrm{BC}$ and PS is greatly improved, as is seen in Figure 5 (the typical flame images of BC and PS particles in $\mathrm{O}_{2} / \mathrm{N}_{2}$ and $\mathrm{O}_{2} / \mathrm{CO}_{2}$ atmospheres at different $\mathrm{O}_{2}$ mole fractions are given in the Supplementary Materials). For BC, when the $\mathrm{O}_{2}$ mole fraction increases from $21-40 \%$, the flames of volatiles and chars become brighter and larger, and the fragmentation of coal particles occurs more frequently. Furthermore, the two-stage 
combustion process becomes less obvious. This is because coal chars are ignited while the volatiles are still burning. For PS, the volatiles flames change from nearly transparent to opaque as the $\mathrm{O}_{2}$ mole fraction increases. In addition, the brightness and size of flames of volatiles and chars are also improved. Unlike $\mathrm{BC}$, an obvious two-stage combustion process is still observed at high $\mathrm{O}_{2}$ mole fractions.

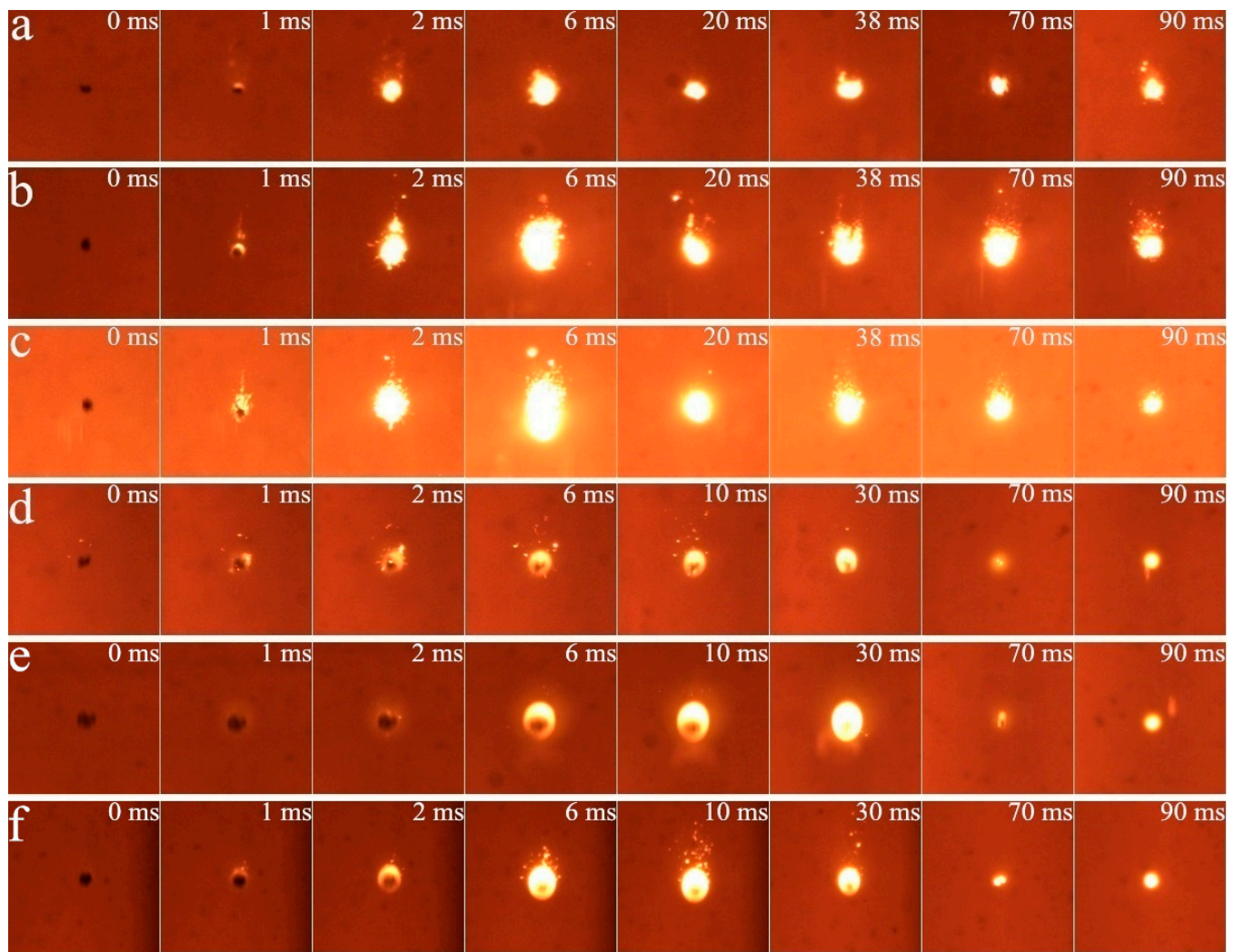

Figure 5. The influences of $\mathrm{O}_{2}$ mole fraction on the combustion characteristics of $\mathrm{BC}$ and PS particles in an $\mathrm{O}_{2} / \mathrm{H}_{2} \mathrm{O}$ atmosphere. (a) $\mathrm{BC}-21 \% \mathrm{O}_{2}+79 \% \mathrm{H}_{2} \mathrm{O}$; (b) $\mathrm{BC}-30 \% \mathrm{O}_{2}+70 \% \mathrm{H}_{2} \mathrm{O}$; (c) $\mathrm{BC}-40 \% \mathrm{O}_{2}+$ $60 \% \mathrm{H}_{2} \mathrm{O}$; (d) $\mathrm{PS}-21 \% \mathrm{O}_{2}+79 \% \mathrm{H}_{2} \mathrm{O}$; (e) $\mathrm{PS}-30 \% \mathrm{O}_{2}+70 \% \mathrm{H}_{2} \mathrm{O}$; and (f) $\mathrm{PS}-40 \% \mathrm{O}_{2}+60 \% \mathrm{H}_{2} \mathrm{O}$.

\subsection{Combustion Temperature}

The peak temperatures of volatiles combustion and char combustion of BC are shown in Figure 6. In order to minimize the error, the error bars were added to the final results [32]. Every experiment was repeated 10 times. The two-color method is not suitable for measuring the temperature of the biomass volatiles flame, which is because the gray-body emissivity assumption may not be valid for such low-soot flames [21,33]. Therefore, only average peak combustion temperatures of PS chars are given in Figure 7. It is clear to see that the peak combustion temperatures depend heavily on the $\mathrm{O}_{2}$ mole fraction, as well as the type of diluent gas. The peak temperatures of $\mathrm{BC}$ and PS increase as the $\mathrm{O}_{2}$ mole fraction increases. The lowest peak temperatures are obtained in $\mathrm{O}_{2} / \mathrm{CO}_{2}$ atmospheres at the same $\mathrm{O}_{2}$ mole fraction, which is due to the lower diffusivity of $\mathrm{O}_{2}$ in $\mathrm{CO}_{2}$ and the larger volumetric heat capacity of $\mathrm{CO}_{2}$.

At a low $\mathrm{O}_{2}$ mole fraction ( $21 \%$ and $30 \%$ cases), the peak temperatures of $\mathrm{BC}$ and $\mathrm{PS}$ in $\mathrm{O}_{2} / \mathrm{H}_{2} \mathrm{O}$ atmospheres are lower than those in $\mathrm{O}_{2} / \mathrm{N}_{2}$ atmospheres. However, the peak temperatures are highest in $\mathrm{O}_{2} / \mathrm{H}_{2} \mathrm{O}$ atmospheres when the $\mathrm{O}_{2}$ mole fraction reaches $40 \%$. There are two kinds of effects of $\mathrm{H}_{2} \mathrm{O}$ on the combustion temperatures of $\mathrm{BC}$ and PS particles. First is the physical effect, the volumetric heat capacity of $\mathrm{H}_{2} \mathrm{O}$ is larger than that of $\mathrm{N}_{2}$, and the emission capacity of $\mathrm{H}_{2} \mathrm{O}$ is higher: these factors will decrease the combustion temperature. Second is the chemical effect: the oxidation effect of $\mathrm{H}_{2} \mathrm{O}$ is stronger than that of $\mathrm{N}_{2}$ or $\mathrm{CO}_{2}$ [13], thus, the oxidation effect of $\mathrm{O}_{2} / \mathrm{H}_{2} \mathrm{O}$ atmospheres is stronger 
than those of $\mathrm{O}_{2} / \mathrm{N}_{2}$ or $\mathrm{O}_{2} / \mathrm{CO}_{2}$ atmospheres, which is beneficial for combustion. Combining with the experimental results, it is clear that the global effect of $\mathrm{H}_{2} \mathrm{O}$ is associated with the mole fraction of $\mathrm{O}_{2}$. At low $\mathrm{O}_{2}$ mole fractions, the $\mathrm{H}_{2} \mathrm{O}$ concentration is high, and the effect of volumetric heat capacity and emission capacity performs a more important role. Thus, the peak temperatures are lower in $\mathrm{O}_{2} / \mathrm{H}_{2} \mathrm{O}$ atmospheres. However, when the mole fraction of $\mathrm{O}_{2}$ reaches $40 \%$, the effect of volumetric heat capacity and emission capacity of $\mathrm{H}_{2} \mathrm{O}$ is minor, and the oxidation causes a greater effect; therefore, the combustion temperatures are increased. At the same condition, the average peak temperatures of char combustion of PS are lower than those of BC, which is because the calorific value of PS is lower.

According to the previous studies [7-9,21], the combustion temperatures of coal and biomass in an $\mathrm{O}_{2} / \mathrm{CO}_{2}$ environment are close to those in air $\left(21 \% \mathrm{O}_{2}\right)$ when the $\mathrm{O}_{2}$ mole fraction increases to $30 \sim 35 \%$, which is in agreement with the results obtained in this study. However, when substituting $\mathrm{H}_{2} \mathrm{O}$ for $\mathrm{N}_{2}$, the combustion temperatures are reduced less and are even higher when the $\mathrm{O}_{2}$ mole fraction reaches $40 \%$.
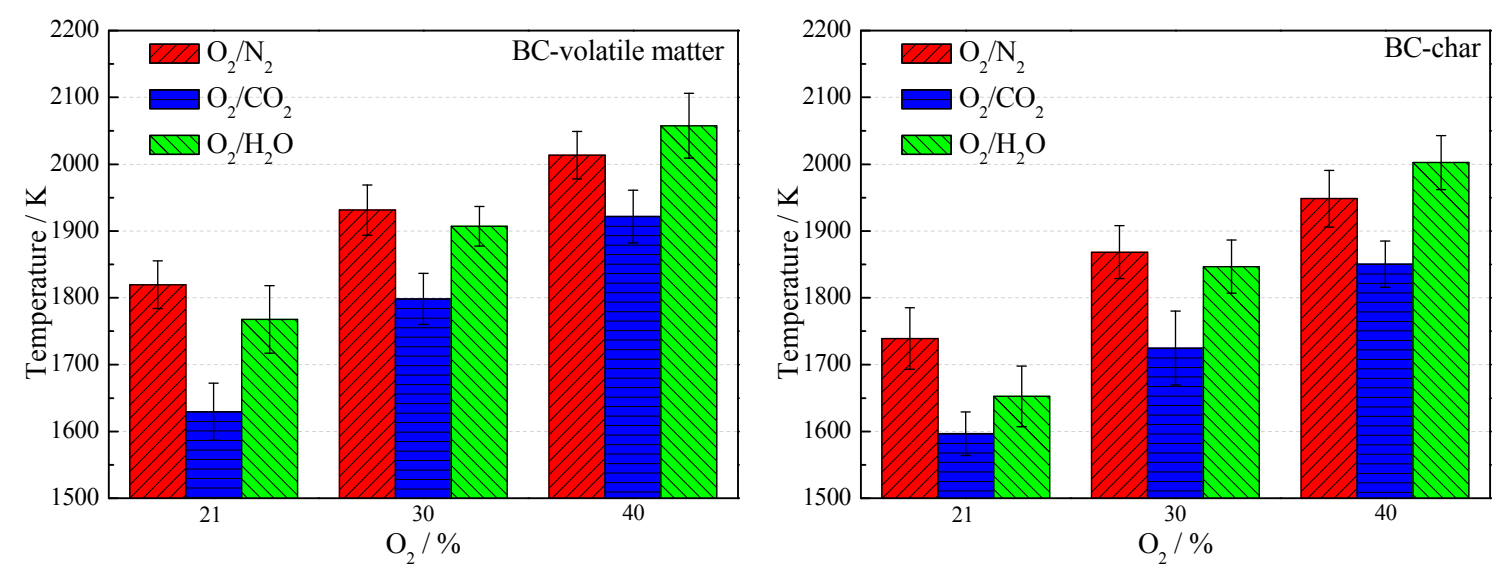

Figure 6. Average peak temperatures of volatiles and chars of BC.

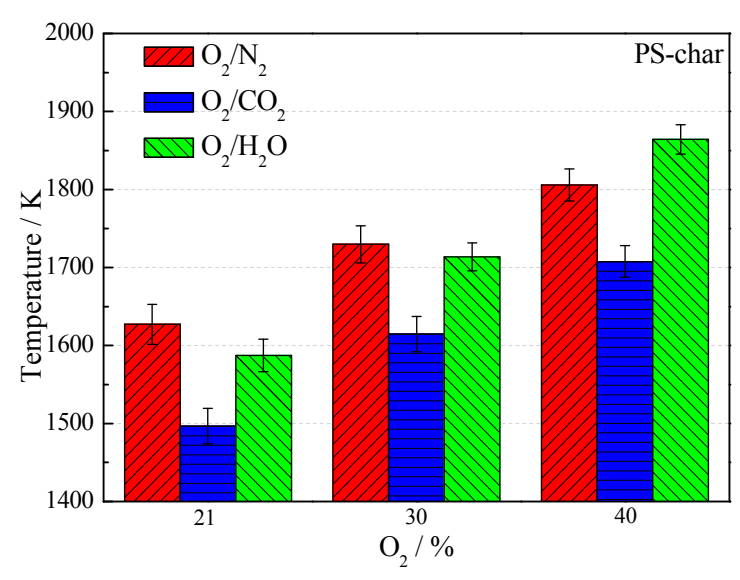

Figure 7. Average peak temperatures of chars of PS.

\subsection{Ignition Delay Time}

The ignition delay time is defined as the time from the particle enters into the furnace until the first visible flame is detected. The error bars were also added to the results of the ignition delay time, and every experiment was repeated 20 times. The ignition delay time of BC and PS under different atmospheres is shown in Figure 8. At the same condition, the ignition of PS particles occurs earlier than $\mathrm{BC}$, which is owing to the lower ignition temperature of PS volatiles. The ignition delay time of $\mathrm{BC}$ 
and PS decreases with an increasing mole fraction of $\mathrm{O}_{2}$, because the oxidation effect of background gas is improved. The ignition delay time of $\mathrm{O}_{2} / \mathrm{CO}_{2}$ atmosphere is longer than that of an $\mathrm{O}_{2} / \mathrm{N}_{2}$ atmosphere at the same $\mathrm{O}_{2}$ mole fraction. This is mainly caused by different physical properties between $\mathrm{CO}_{2}$ and $\mathrm{N}_{2}$. In an $\mathrm{O}_{2} / \mathrm{CO}_{2}$ atmosphere, the gas temperature is lower than that in an $\mathrm{O}_{2} / \mathrm{N}_{2}$ atmosphere because of the larger volumetric heat capacity of $\mathrm{CO}_{2}$. Therefore, the ignition occurs later in the $\mathrm{O}_{2} / \mathrm{CO}_{2}$ environment.
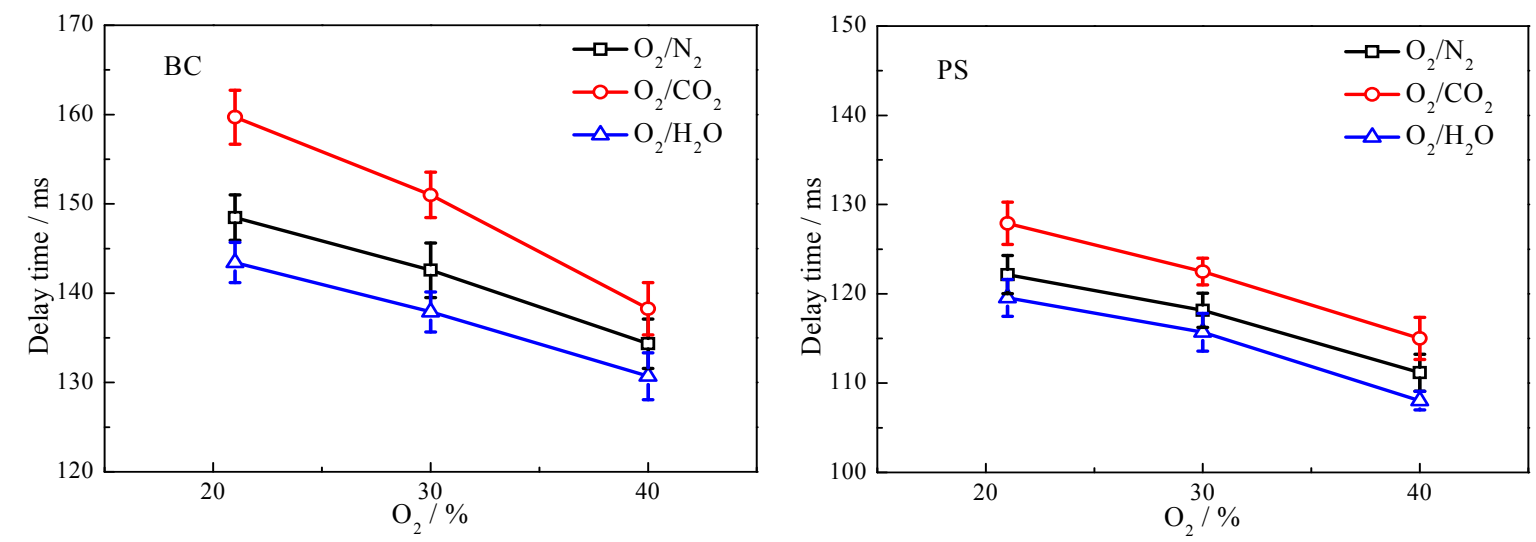

Figure 8. Ignition delay time of BC and PS under different atmospheres.

On the contrary, replacing $\mathrm{N}_{2}$ with $\mathrm{H}_{2} \mathrm{O}$ leads to the earlier ignition of fuel particles. This is caused by the different physical and chemical properties between $\mathrm{H}_{2} \mathrm{O}$ and $\mathrm{N}_{2}$. In terms of physical properties, the volumetric heat capacity of $\mathrm{H}_{2} \mathrm{O}$ is larger than that of $\mathrm{N}_{2}$ at $1273 \mathrm{~K}$, similar to the $\mathrm{O}_{2} / \mathrm{CO}_{2}$ environment, the higher volumetric heat capacity of $\mathrm{H}_{2} \mathrm{O}$ will result in ignition delay in the $\mathrm{O}_{2} / \mathrm{H}_{2} \mathrm{O}$ environment. In terms of chemical properties, there are two aspects. During the heating stage of fuel particles in the $\mathrm{O}_{2} / \mathrm{H}_{2} \mathrm{O}$ environment, the steam gasification reaction and steam shift reaction will start $[11,12]$. The chemical equations of the steam gasification reaction and steam shift reaction are given in Equations (8) and (9), respectively:

$$
\begin{gathered}
\mathrm{C}+\mathrm{H}_{2} \mathrm{O} \rightarrow \mathrm{CO}+\mathrm{H}_{2}, \Delta \mathrm{H}=130 \mathrm{KJ} / \mathrm{mol} \\
\mathrm{CO}+\mathrm{H}_{2} \mathrm{O} \rightarrow \mathrm{CO}_{2}+\mathrm{H}_{2}, \Delta \mathrm{H}=-40.9 \mathrm{KJ} / \mathrm{mol}
\end{gathered}
$$

Firstly, the steam gasification reaction is an endothermic reaction and will reduce the particle temperature, which is detrimental to ignition. However, the products of this reaction (CO and $\mathrm{H}_{2}$ ) are beneficial to shorten the ignition delay time because of their lower ignition temperatures. Secondly, the steam shift reaction is an exothermic reaction and this reaction also produces $\mathrm{H}_{2}$. Therefore, the steam shift reaction is beneficial to ignition.

From the above analysis, it can be seen that the influence of $\mathrm{H}_{2} \mathrm{O}$ on ignition delay is diversified. Combining with the experimental results, it can be inferred that the factors leading to earlier ignition have a greater effect in the $\mathrm{O}_{2} / \mathrm{H}_{2} \mathrm{O}$ environment. Previous studies reported that the ignition of coal and biomass chars would be delayed with the addition of $\mathrm{H}_{2} \mathrm{O}$ [15-17]. However, the ignition of $\mathrm{BC}$ and PS particles is promoted in this study. Therefore, it can be inferred that the volatiles of $\mathrm{BC}$ and PS perform a crucial role during the ignition process in the $\mathrm{O}_{2} / \mathrm{H}_{2} \mathrm{O}$ environment. For $\mathrm{BC}$ and PS, their volatiles contain $\mathrm{CO}$ that can readily react with $\mathrm{H}_{2} \mathrm{O}[6,14,21]$. Thus, the steam shift reaction has a greater effect on the ignition of BC and PS particles in this study. However, the coal and biomass chars contain no volatiles, therefore, there is no steam shift reaction. The steam gasification reaction has a small effect on ignition because of its low reaction rate. Therefore, the physical properties of $\mathrm{H}_{2} \mathrm{O}$ have a greater effect of the ignition of chars and result in a longer ignition delay time. 


\section{Conclusions}

In this study, the combustion characteristics of single particles from $\mathrm{BC}$ and $\mathrm{PS}$ in $\mathrm{O}_{2} / \mathrm{N}_{2}, \mathrm{O}_{2} / \mathrm{CO}_{2}$ and $\mathrm{O}_{2} / \mathrm{H}_{2} \mathrm{O}$ atmospheres at different $\mathrm{O}_{2}$ mole fractions $(21 \%, 30 \%$ and $40 \%)$ were investigated. The results reveal that the particles from $\mathrm{BC}$ and PS all ignite homogeneously in $\mathrm{O}_{2} / \mathrm{N}_{2}, \mathrm{O}_{2} / \mathrm{CO}_{2}$ and $\mathrm{O}_{2} / \mathrm{H}_{2} \mathrm{O}$ atmospheres. As the $\mathrm{O}_{2}$ mole fraction increases, the ignition delay time becomes shorter and the combustion temperatures are increased. By replacing $\mathrm{N}_{2}$ with $\mathrm{CO}_{2}$, the ignition delayed time is extended and the combustion temperatures are decreased. By replacing $\mathrm{N}_{2}$ with $\mathrm{H}_{2} \mathrm{O}$, the ignition occurs earlier, and the combustion temperatures are decreased at a low $\mathrm{O}_{2}$ mole fraction, while increased at a high $\mathrm{O}_{2}$ mole fraction. Under the same condition, the ignition of PS particles occurs earlier, while the combustion temperatures are lower than those of $\mathrm{BC}$.

Comparing with $\mathrm{O}_{2} / \mathrm{CO}_{2}$ recycled combustion, $\mathrm{O}_{2} / \mathrm{H}_{2} \mathrm{O}$ combustion can not only achieve the capture and storage of $\mathrm{CO}_{2}$, but also maintains a higher combustion temperature of $\mathrm{BC}$ and PS. In addition, the ignition delay time is shortest in the $\mathrm{O}_{2} / \mathrm{H}_{2} \mathrm{O}$ environment. Therefore, burning $\mathrm{BC}$ and pine sawdust in an $\mathrm{O}_{2} / \mathrm{H}_{2} \mathrm{O}$ environment is a more competitive technology for facilitating CCS.

Supplementary Materials: The following are available online at www.mdpi.com/1996-1073/10/11/1695/s1, Figure S1: The influences of $\mathrm{O}_{2}$ mole fraction on the combustion characteristics of $\mathrm{BC}$ particles in an $\mathrm{O}_{2} / \mathrm{N}_{2}$ atmosphere. (a) $\mathrm{BC}-21 \% \mathrm{O}_{2}+79 \% \mathrm{~N}_{2}$; (b) $\mathrm{BC}-30 \% \mathrm{O}_{2}+70 \% \mathrm{~N}_{2}$; and (c) $\mathrm{BC}-40 \% \mathrm{O}_{2}+60 \% \mathrm{~N}_{2}$, Figure S2: The influences of $\mathrm{O}_{2}$ mole fraction on the combustion characteristics of PS particles in an $\mathrm{O}_{2} / \mathrm{N}_{2}$ atmosphere. (a) PS- $21 \% \mathrm{O}_{2}+79 \% \mathrm{~N}_{2}$; (b) PS- $30 \% \mathrm{O}_{2}+70 \% \mathrm{~N}_{2}$; and (c) $\mathrm{PS}-40 \% \mathrm{O}_{2}+60 \% \mathrm{~N}_{2}$, Figure S3: The influences of $\mathrm{O}_{2}$ mole fraction on the combustion characteristics of bituminous coal particles in an $\mathrm{O}_{2} / \mathrm{CO}_{2}$ atmosphere. (a) $\mathrm{BC}-21 \% \mathrm{O}_{2}+$ $79 \% \mathrm{CO}_{2} ;$ (b) $\mathrm{BC}-30 \% \mathrm{O}_{2}+70 \% \mathrm{CO}_{2}$; and (c) $\mathrm{BC}-40 \% \mathrm{O}_{2}+60 \% \mathrm{CO}_{2}$, Figure S4: The influences of $\mathrm{O}_{2}$ mole fraction on the combustion characteristics of PS particles in an $\mathrm{O}_{2} / \mathrm{CO}_{2}$ atmosphere. (a) $\mathrm{PS}-21 \% \mathrm{O}_{2}+79 \% \mathrm{CO}_{2}$; (b) $\mathrm{PS}-30 \% \mathrm{O}_{2}$ $+70 \% \mathrm{CO}_{2} ;$ and (c) $\mathrm{PS}-40 \% \mathrm{O}_{2}+60 \% \mathrm{CO}_{2}$.

Acknowledgments: The authors gratefully acknowledge the support from the National Natural Science Foundation of China (51506091, 51576100), the National Key R\&D Program of China (No. 2016YFB0600100), and the Fundamental Research Funds for the Central Universities (30915011325).

Author Contributions: Kai Lei performed the experiments, analyzed the data, and wrote the paper; Rui Zhang supervised this project, designed the experiments, and revised the paper; Buqing Ye and Jin Cao helped with the experiments and analyzed the data; and Dong Liu revised the paper and discussed.

Conflicts of Interest: The authors declare no conflict of interest.

\section{References}

1. British Petroleum. Statistical Review of World Energy; BP: London, UK, 2016.

2. Li, Y.; Niu, D.; Cao, Y.; Hong, W. Analysis and Modeling for China's Electricity Demand Forecasting Using a Hybrid Method Based on Multiple Regression and Extreme Learning Machine: A View from Carbon Emission. Energies 2016, 9, 941. [CrossRef]

3. Warner, K.J.; Jones, G.A. The Climate-Independent Need for Renewable Energy in the 21st Century. Energies 2017, 10, 1197. [CrossRef]

4. Mondino, G.; Grande, C.A.; Blom, R. Effect of Gas Recycling on the Performance of a Moving Bed Temperature-Swing (MBTSA) Process for $\mathrm{CO}_{2}$ Capture in a Coal Fired Power Plant Context. Energies 2017, 10, 745. [CrossRef]

5. Rathnam, R.K.; Elliott, L.K.; Wall, T.F.; Liu, Y.; Moghtaderi, B. Differences in reactivity of pulverised coal in air $\left(\mathrm{O}_{2} / \mathrm{N}_{2}\right)$ and oxy-fuel $\left(\mathrm{O}_{2} / \mathrm{CO}_{2}\right)$ conditions. Fuel Process. Technol. 2009, 90, 797-802. [CrossRef]

6. Khatami, R.; Stivers, C.; Levendis, Y.A. Ignition characteristics of single coal particles from three different ranks in $\mathrm{O}_{2} / \mathrm{N}_{2}$ and $\mathrm{O}_{2} / \mathrm{CO}_{2}$ atmospheres. Combust. Flame 2012, 159, 3554-3568. [CrossRef]

7. Khatami, R.; Stivers, C.; Joshi, K.; Levendis, Y.A.; Sarofim, A.F. Combustion behavior of single particles from three different coal ranks and from sugar cane bagasse in $\mathrm{O}_{2} / \mathrm{N}_{2}$ and $\mathrm{O}_{2} / \mathrm{CO}_{2}$ atmospheres. Combust. Flame 2012, 159, 1253-1271. [CrossRef]

8. Zhang, L.; Binner, E.; Qiao, Y.; Li, C. In situ diagnostics of Victorian brown coal combustion in $\mathrm{O}_{2} / \mathrm{N}_{2}$ and $\mathrm{O}_{2} / \mathrm{CO}_{2}$ mixtures in drop-tube furnace. Fuel 2010, 89, 2703-2712. [CrossRef]

9. Bejarano, P.A.; Levendis, Y.A. Single-coal-particle combustion in $\mathrm{O}_{2} / \mathrm{N}_{2}$ and $\mathrm{O}_{2} / \mathrm{CO}_{2}$ environments. Combust. Flame 2008, 153, 270-287. [CrossRef] 
10. Seepana, S.; Jayanti, S. Steam-moderated oxy-fuel combustion. Energy Convers. Manag. 2010, 51, 1981-1988. [CrossRef]

11. Zou, C.; Cai, L.; Wu, D.; Liu, Y.; Liu, S.; Zheng, C. Ignition behaviors of pulverized coal particles in $\mathrm{O}_{2} / \mathrm{N}_{2}$ and $\mathrm{O}_{2} / \mathrm{H}_{2} \mathrm{O}$ mixtures in a drop tube furnace using flame monitoring techniques. Proc. Combust. Inst. 2015, 35, 3629-3636. [CrossRef]

12. Cai, L.; Zou, C.; Liu, Y.; Zhou, K.; Han, Q.; Zheng, C. Numerical and experimental studies on the ignition of pulverized coal in $\mathrm{O}_{2} / \mathrm{H}_{2} \mathrm{O}$ atmospheres. Fuel 2015, 139, 198-205. [CrossRef]

13. Cai, L.; Zou, C.; Guan, Y.; Jia, H.; Zhang, L.; Zheng, C. Effect of steam on ignition of pulverized coal particles in oxy-fuel combustion in a drop tube furnace. Fuel 2016, 182, 958-966. [CrossRef]

14. Prationo, W.; Zhang, L. Influence of steam on ignition of Victorian brown coal particle stream in oxy-fuel combustion: In-situ diagnosis and transient ignition modelling. Fuel 2016, 181, 1203-1213. [CrossRef]

15. Gil, M.V.; Riaza, J.; Álvarez, L.; Pevida, C.; Pis, J.J.; Rubiera, F. A study of oxy-coal combustion with steam addition and biomass blending by thermogravimetric analysis. J. Therm. Anal. Calorim. 2012, 109, 49-55. [CrossRef]

16. Yi, B.; Zhang, L.; Huang, F.; Mao, Z.; Zheng, C. Effect of $\mathrm{H}_{2} \mathrm{O}$ on the combustion characteristics of pulverized coal in $\mathrm{O}_{2} / \mathrm{CO}_{2}$ atmosphere. Appl. Energy 2014, 132, 349-357. [CrossRef]

17. Zou, C.; Zhang, L.; Cao, S.; Zheng, C. A study of combustion characteristics of pulverized coal in $\mathrm{O}_{2} / \mathrm{H}_{2} \mathrm{O}$ atmosphere. Fuel 2014, 115, 312-320. [CrossRef]

18. Cuellar, A.D.; Herzog, H. A Path Forward for Low Carbon Power from Biomass. Energies 2015, 8, $1701-1715$. [CrossRef]

19. Arce, M.E.; Saavedra, A.; Míguez, J.L.; Granada, E.; Cacabelos, A. Biomass Fuel and Combustion Conditions Selection in a Fixed Bed Combustor. Energies 2013, 6, 5973-5989. [CrossRef]

20. Wang, C.; Zhang, L.; Yang, S.; Pang, M. A Hybrid Life-Cycle Assessment of Nonrenewable Energy and Greenhouse-Gas Emissions of a Village-Level Biomass Gasification Project in China. Energies 2012, 5, 2708-2723. [CrossRef]

21. Riaza, J.; Khatami, R.; Levendis, Y.A.; Álvarez, L.; Gil, M.V.; Pevida, C.; Rubiera, F.; Pis, J.J. Combustion of single biomass particles in air and in oxy-fuel conditions. Biomass Bioenergy 2014, 64, 162-174. [CrossRef]

22. Li, R.; Kai, X.; Yang, T.; Sun, Y.; He, Y.; Shen, S. Release and transformation of alkali metals during co-combustion of coal and sulfur-rich wheat straw. Energy Convers. Manag. 2014, 83, 197-202. [CrossRef]

23. Tillman, D.A. Biomass cofring: The technology, the experience, the combustion consequences. Biomass Bioenergy 2000, 19, 365-384. [CrossRef]

24. Baxter, L. Biomass-coal co-combustion: Opportunity for affordable renewable energy. Fuel 2005, 84, 1295-1302. [CrossRef]

25. Riaza, J.; Gil, M.V.; Pevida, C.; Pis, J.J.; Rubiera, F. Oxy-fuel combustion of coal and biomass blends. Energy 2012, 41, 429-435. [CrossRef]

26. Zhou, H.; Li, Y.; Li, N.; Qiu, R.; Cen, K. NO and $\mathrm{N}_{2} \mathrm{O}$ Emissions during Devolatilization and Char Combustion of a Single Biomass Particle under Oxy-fuel Conditions at Fluidized Bed Temperature. Energy Fuels 2017, 31, 7157-7165. [CrossRef]

27. Molina, A.; Shaddix, C.R. Ignition and devolatilization of pulverized bituminous coal particles during oxygen/carbon dioxide coal combustion. Proc. Combust. Inst. 2007, 31, 1905-1912. [CrossRef]

28. Guizani, C.; Jeguirim, M.; Valin, S.; Limousy, L.; Salvador, S. Biomass Chars: The Effects of Pyrolysis Conditions on Their Morphology, Structure, Chemical Properties and Reactivity. Energies 2017, 10, 796. [CrossRef]

29. Wang, G.; Zhang, J.; Shao, J.; Liu, Z.; Zhang, G.; Xu, T.; Guo, J.; Wang, H.; Xu, R.; Lin, H. Thermal behavior and kinetic analysis of co-combustion of waste biomass/low rank coal blends. Energy Convers. Manag. 2016, 124, 414-426. [CrossRef]

30. Luo, Z.X.; Zhou, H.C. A Combustion-Monitoring System with 3-D Temperature Reconstruction Based on Flame-Image Processing Technique. IEEE Trans. Instrum. Meas. 2007, 56, 1877-1882. [CrossRef]

31. Zhou, H.C.; Lou, C.; Cheng, Q.; Jiang, Z.W.; He, J.; Huang, B.Y.; Pei, Z.L.; Lu, C.X. Experimental investigations on visualization of three-dimensional temperature distributions in a large-scale pulverized-coal-fired boiler furnace. Proc. Combust. Inst. 2005, 30, 1699-1706. [CrossRef] 
32. Harris, D.C. Quantitative Chemical Analysis; WH Freeman: New York, NY, USA, 2010.

33. Khatami, R.; Levendis, Y.A. On the deduction of single coal particle combustion temperature from three-color optical pyrometry. Combust. Flame 2011, 158, 1822-1836. [CrossRef] 